\title{
RE-DEVELOPMENT OF TOURISM AREA IN SUMBER JENON SPRING WATER TAJINAN SUB DISTRICT, MALANG REGENCY
}

\author{
Mohammad Reza $^{1 *}$, Agung Witjaksono ${ }^{2}$ \\ ${ }^{1,2}$ Urban and Regional Planning, Faculty of Civil Engineering and Planning (FTSP), \\ National Institute of Technology (ITN) Malang, Indonesia
}

*Corresponding Email: rz.abang@gmail.com

\begin{abstract}
The area of Jenon Spring Water has been determined as tourism development area in Malang Regency. Public facilities and services are a variety of physical buildings and structured programs that play a role in improving the comfort of a residential environment. Public and social services and facilities are very important in the life of city residents. This research is aimed to arrange the spatial development brief of Jenon Spring Water. The method used in this research is descriptive qualitative method. The research result show that regional arrangement is needed. Where in the area arrangement in Sumber Jenon carried out in this project has a positive effect in Gunungronggo Village, which can improve the economy of the Gunungronggo Village community and improve the quality of Human Resources in Gunungronggo Village by adding a souvenir store and other facilities in Sumber Jenon.
\end{abstract}

Keywords: Spring Water, Improve Economy, Tourism Development Area

\section{Introduction}

Development is one of the characteristics inherent in every region or city. These developments vary, starting from the development of the population, followed by the development of the activities of the population and so on. The development of the population and its activities must be balanced with the development of facilities, because facilities are the support and support for the activities of the population. Every facility needed by the population must develop both in quantity and quality as the population increases.

Public facilities and services are a variety of physical buildings and structured programs that play a role in improving the comfort of a residential environment. Public and social services and facilities are very important in the life of city residents. On the other hand, the service of these facilities is an important and main task of the local city government.

Sumber Jenon is one of the natural springs that located in Malang Regency. This pond has a depth of about 6.5 meters, with a length of about $50 \mathrm{~m}$ and a width of $30 \mathrm{~m}$. Sumber Jenon is in the sub- district of Tajinan, Malang Regency, East Java. From the city of Malang, it is about a 30-minute walk to Cemoro Kandang or
Tumpang District.

What's interesting about Sumber Jenon is the atmosphere of the pond which is full of mystical aura. The pond is surrounded by big, tall banyan trees. The leaf canopy almost covers the surface of the pond. The yellow, fallen leaves add to the scary atmosphere. On the other hand, Jenon's source was saved by the local community. At certain times there are those who put up offerings. The sanctity of this place is really maintained to keep it intact. The myths that have developed are actually very beneficial ecologically, namely they can protect the place in order to remain sustainable. Thus, conservation based on local wisdom is very effective in protecting this place.

One of the springs which is now a unique and well-known tourist center around Malang Raya. The name Sumber Jenon itself is taken from the jenu tree which collapsed and springs out. The longer the water was stagnant and he made a $4 \mathrm{~km}$ long river so that the water could flow into his hut. The process of making the river was done overnight with the knowledge possessed by mbah wiro. Seeing the water has flowed, the wife was happy and thought her husband would come home. But what came was only the white lion, not her husband. The white lion is considered to be the incarnation of Mbah Wiro. So that this village is called the white lion 
dayangan. If one day the era progresses, Mbah Wiro tells that this source will be named Sumber Jenupoo because of the collapse of the jenu tree. However, due to modernization, today's society calls it Sumber Jenon. This source, which is located in the village of Mount Ronggo, Tajinan sub-district, Malang district, seems to offer a place for bathing, diving as well as therapy for various diseases, such as skin diseases. Local residents not only believe in this source as a tourist place, but also believe in an effective healing medium.

Even though it keeps the beauty and historical values, the condition of Sumber Jenon baths is still under-noticed. Access to the footpath to Sumber Jenon has been damaged and supporting facilities that are lacking are a problem with the Sumber Jenon bathhouse. It is no wonder that Sumber Jenon's condition is currently not being maintained and is just being left alone. Not only does the government pay less attention, the local villagers also seem indifferent to the cultural tourism potential of Sumber Jenon.

\section{Research Purposes}

The purpose of this study is to identify the need for facilities and utilities to realize ecobased tourism at Sumber Jenon

\section{Benefit of Researches}

This research can provide information \& recommendation to Gunungronggo management, Gunungronggo Community, and Tourism and Culture Office of Malang Regency in arranging the Sumber Jenon tourism area.

\section{Literature Review}

\subsection{Natural Resources}

Natural resources such as water, air, land, oil, fish, forests, etc. are very important resources for human survival. In general, natural resources can be classified into two groups: First, the stock group that these resources are considered to have limited reserves so that the exploitation of these resources will consume the resource reserves. Second, the second group is natural resources which are called "flows". In this type of resource, the physical quantity of the resource changes over time [1].

\subsection{Water Resources Management Model}

Management of fresh water resources needs to combine various social and economic aspects. Management of water resources that can be carried out is by using three strategies, namely, resource conservation, pollution control, use regulation with three strategies, resource conservation, control, pollution and regulation, use with three scenarios, so that more water reserves, quality water is better, and water resources can be used longer [2].

\subsection{Tourism}

Tourism is a trip taken by a person within a certain period of time from one place to another by planning ahead, for recreation or for an interest so that his wishes can be fulfilled. Tourism is not just a service provided by tourism industry as a form of meeting the needs of tourists, both from before being in a tourist destination to when doing tourist activities. However, there are tourism factors or components that are important in supporting the successful development of an area as a tourism destination. In a tourism system there are six components, namely: accessibility, tourist attractions, accommodation, facilities, activities, additional services [3]

\section{Research Method}

\subsection{Study Scope and Research Area}

The scope area of this research is Jenon spring water tourism destinations in the gunungronggo village, Tajinan sub district, Malang regency.

\subsection{Research Method and Data Analysis}

The method used in this research is descriptive qualitative method by showing the problem to be studied. In this case the field survey method will be used which is a stage to obtain data or information on the research area so that a clear picture of the area can be found. Qualitative data is data used to classify characteristics, shapes and words. Includes data on the condition of facilities and infrastructure in the tourist area of Sumber Jenon, as shown in the Figure 1.

Sources of data from this study are primary data and secondary data, where primary data 
obtained through field surveys at the location of tourist objects are the physical conditions of the survey environment, the conditions of tourism facilities and infrastructure.

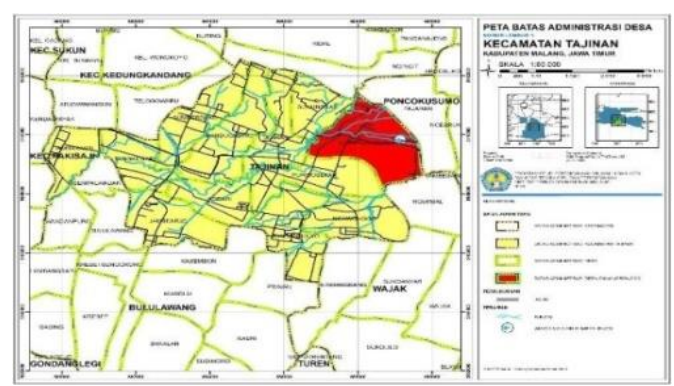

Figure 1 Administration Border Map of Tajinan Sub District

\section{Result and Discussion}

\subsection{Society's Socio-Economy Condition}

The majority of people living in Gunungronggo Village are farming fields and raising livestock. Meanwhile, most of the youth in Gunungronggo Village chose to migrate to the city as laborers or construction workers.

\subsection{Tourism Concept Sumber Jenon Spring Water Area}

\subsubsection{Access Point}

Sumber Jenon does have an entrance, so it is necessary to add some flower plants along the path to the pond, as shown in Figure 2. Because the road from the ticket booth to the pond is rather steep, so that the right side of the stairs is added to make it easier for visitors, but the left side is not changed due to anticipation of visitors bringing baby strollers.

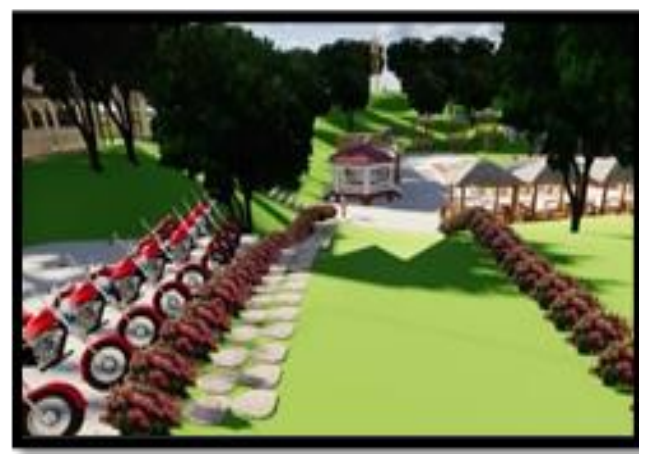

Figure 2 Entry Gate Design of Sumber Jenon

\subsubsection{Gazebo Design}

The Gazebo near the pond was added because usually not all visitors come to Sumber Jenon to swim but some come just to enjoy the natural atmosphere in Sumber Jenon. So added a Gazebo on the right side and lounge chairs around the pond. In addition, at the end of the left side there is a rental place for swimming equipment such as tires, buoys and diving equipment, as shown in Figure 3.

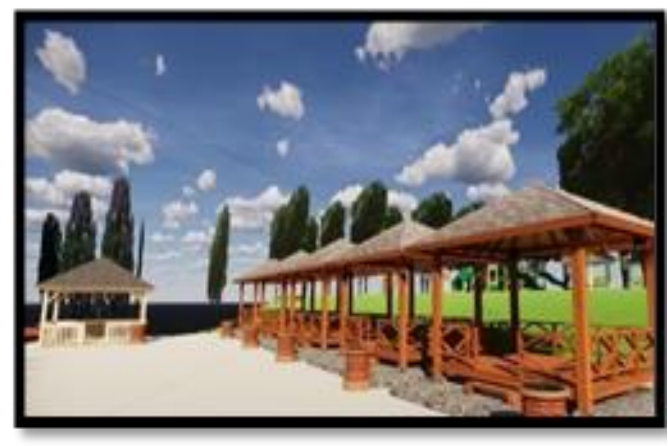

Figure 3 Gazebo Design and Swimming Equipment Rental Site

\subsubsection{Information center and Mushola}

Information Center which already available and comes with the prayer room. But the thing that must get an attention is the positioning so that it will be easier to access by visitor who have already been in souvenir store or near the pond. The place for ablution is made of bamboo and seperate for men and women, as shown in Figure 4.

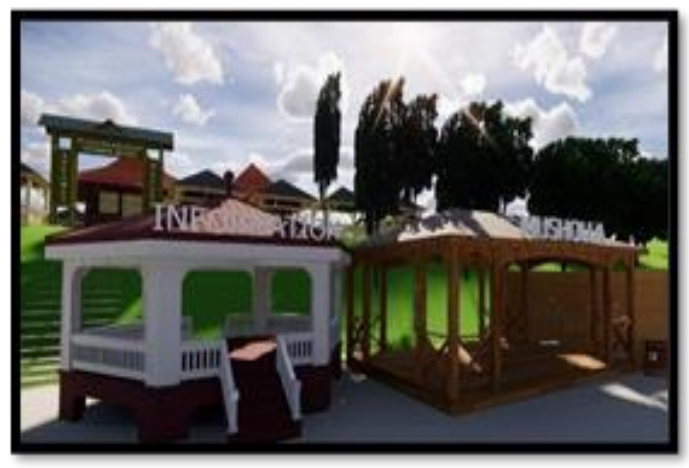

Figure 4 Information Center Design and Mushola

\subsubsection{Public Bathroom Design}

Public bathrooms at Sumber Jenon are made as comfortable as possible and easy to reach for visitors, besides that, around the public bathrooms, a pavilion is provided to relax or wait for the queue to enter the bathroom, as shown in Figure 5. 


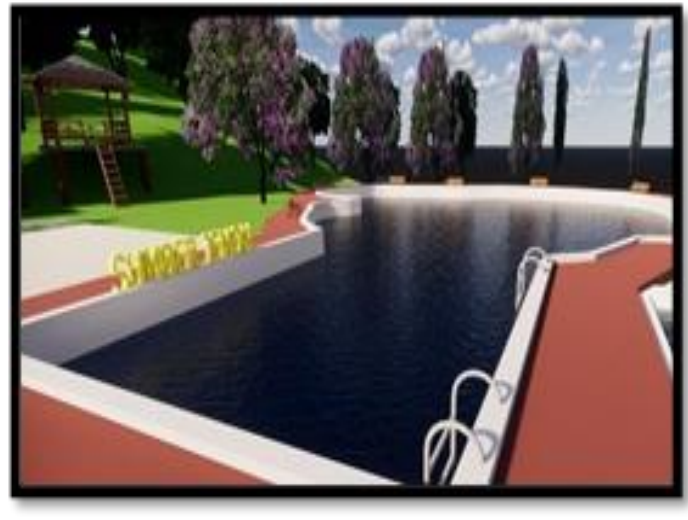

Figure 5 Public Bathroom Design

\subsubsection{Spring Water Pond}

In this Jenon source pond there is no changes in shape, but there are only additional attributes such as a handle on the pond and garden chairs, as shown in Figure 6. The addition of this attribute is intended to make it easier for visitors who are in the pond, or those who are just lounging on the edge of the pond.

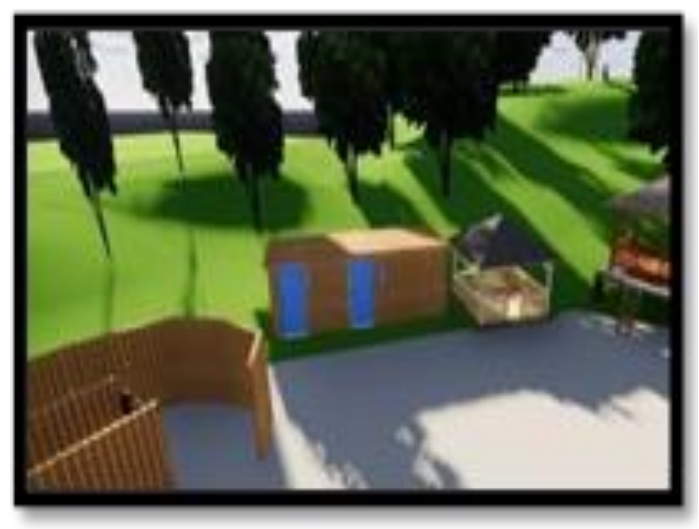

Figure 6 Spring Water Pond Design

\subsubsection{Souvenir Store}

The addition of the Sumber Jenon souvenir store is intended for the people of Gunungronggo Village so that the people of Gunungronggo Village can sell special processed products that can help the community's economy. In addition, in this souvenir store area, there is also a pavilion that can be used if visitors want to take a break after shopping, as shown on Figure 7. This souvenir store is made towards the exit gate so that if visitors want to go home, they will definitely pass through this souvenir store.

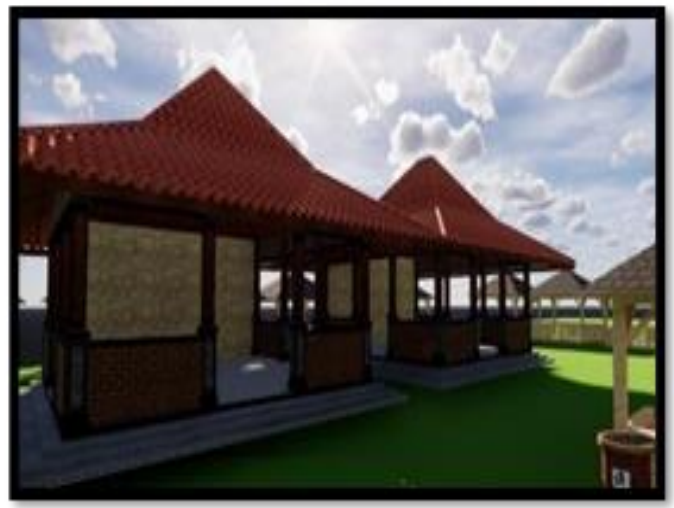

Figure 7 Souvenir Store Design

\subsubsection{Exit Gate}

The exit gate from the souvenir store is made directly into the parking lot to make it easier for visitors. In addition, seeing the existing condition of the parking lot at Sumber Jenon which is quite wide, it can accommodate quite a number of two- wheeled vehicles and four-wheeled vehicles, as shown in Figure 8.

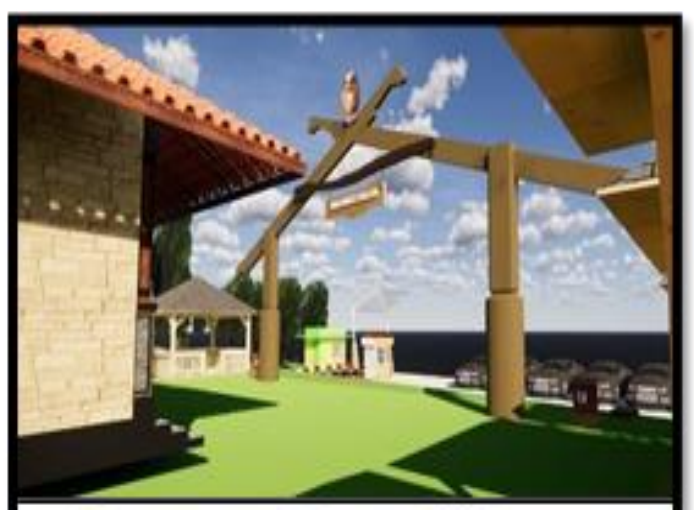

Figure 8 Design Exit Gate Jenon Spring Water Area

\section{Conclusion and Recommendation}

\subsection{Conclusion}

To support the efforts of Sumber Jenon activities to run smoothly and to be better known not only by the people of Gunungronggo Village or its surroundings but also people outside the Greater Malang area as well as foreign tourists, therefore it is necessary to have an arrangement of the area.

Where the arrangement of the area at Sumber Jenon is carried out as an effort to have a positive effect on Gunungronggo Village, namely that it can improve the economy of the 
Gunungronggo Village community and improve the quality of the Gunungronggo Village human resources by adding a central area for souvenirs at Sumber Jenon. The arrangement of the area at Sumber Jenon includes the addition of stair facilities around the entrance, the location of the information section and prayer room, the rental place for swimming equipment, the addition of existing attributes in the pond, the souvenir store and the exit gate.

\subsection{Recommendation}

1. To the management

Recommendation to the management is to obeserve and maintain every facilities which support various activities for safety and comfort reason.

2. To Gunungronggo Community

To preserve sumber jenon in order to keep its beauty, contribution from the staff, the local, and the government are needed for the sake of natural beauty, balance, and sustainability at Sumber Jenon

3. To Tourism and Culture Office of Malang Regency

In this case, Tourism and Culture Office of Malang Regency is expected to facilitate various tourism which are still not yet known by the majority of public in order to develop. Through this development it is expected to attract local and international visitors.

\section{References}

[1] Triastianti , R. D., Nasirudin ,

Sukirno \& Warsiyah . (2017). Konservasi Sumber Daya Air dan Lingkungan Melalui Kearifan Lokal di Desa Margodado Kecamatan Seyegen Kabupaten Yogyakarta . Kawistara, 207314.

[2] Purwadhi, F. S., \& Haryani , N. S. (2017). Penyusunan Alternatif Pengelolaan Sumber Daya Air Tawar di Pulau Nunukan Berbasis Data Inderaja dan Sistem In Form As I Geografis . 34-49.

[3] Hermawati, P. R. (2020). Komponen Kepariwisataan dan Pengembahan Community Based Tourism di Desa Wisata Nglanggeran . ejournal bsi , 3143. 